\title{
ANALISIS KARYA SENI KERAJINAN ANYAM TALI KUR SISWA KELAS X MADRASAH ALIYAH NEGERI 1 STABAT BERDASARKAN TEKNIK BENTUKDAN WARNA
}

\author{
Citra Sari Ujung $^{1^{*}}$, Chairani $^{{ }^{*}}$ \\ Program Studi Pendidikan Seni Rupa, Jurusan Seni Rupa, Fakultas Bahasa dan Seni \\ Universitas Negeri Medan \\ Email: yunika_naibaho@yahoo.com
}

\begin{abstract}
ABSTRAK
Penelitian ini dilakukan diMadrasah Aliyah Negeri 1 Stabat yang bertujuan untuk mengetahui serta mendeskripsikan hasil analisis karya kerajinan anyam tali kur siswa kelas X Madrasah Aliyah Negeri 1 Stabat berdasarkan teknik bentuk dan warna.Sampel pada penelitian ini menggunakan teknik proporsive sampling(Bertujuan). Adalah teknik pengambilan sampel didasarkan pada tujuan tertentu dengan memperhatikan ciri-ciri dan karakteristik populasi.penelitian ini adalah karya siswa Kelas X Madrasah Aliyah Negeri 1 Stabat yg berjumlah 35 karya. Pengumpulan data dilakukan melalui instrument penelitian, observasi, dokumentasi dan wawancara bertanya langsung dengan para siswa.Dari penelitian yang dilakukan secara keseluruhan berdasarkan pengamatan aspek-aspek yang telah ditentukan, maka siswa kelas X Madrasah Aliyah Negeri 1 Stabat dapat diketahui hasil karya seni kerajinan tali kur mengalami perubahan dan lebih baik. Teknik yang dipakai pada hasil karya anyam siswa Kelas X Madrasah Aliyah Negeri 1 Stabat adalah teknik anyaman cengkeh dan simpul pangkal, simpul kordon. Bentuk yang dipakai pada hasil karya anyam siswa Kelas X Madrasah Aliyah Negeri 1, Hasil menunjukan adalah anyaman tas, gelang tangan, tempat minum, tempat tisu, tas dompet. Penggunaan warna menunjukan warna yang selaras, kombinasi warna dan susunan warna yang kontras, tetapi ada juga yang memakai satu warna.
\end{abstract}

Kata Kunci:Anyaman Tali kur Teknik, Bentuk, dan Warna 


\section{PENDAHULUAN}

Pendidikan Seni Budaya merupakan satu diantara mata pelajaran yang ada di sekolah. Mata pelajaran Seni Budaya merupakan mata pelajaran yang memberikan pembelajaran kepada anak didik mengenai suatu keahlian untuk mengekspresikan ide-ide dan pemikiran estetika, termasuk mewujudkan kemampuan serta imajinasi penciptaan benda, suasana, atau karya yang menimbulkan rasa indah. Ide-ide atau gagasan estetika tersebut memiliki nilai berkarakter budaya sesuai dengan perkembangan zamannya. Untuk itu, Seni budaya sebagai pelajaran yang bertujuan memberikan kesempatan kepada siswa untuk terlibat didalam berbagai pengalaman apresiasi maupun pengalaman berkreasi untuk menghasilkan karya seni yang bermanfaat langsung bagi kehidupaan siswa, terutama pengembangan kreativitasnya.

Dalam pembagian seni budaya ada beberapa macam bagian seni yaitu seni tari, seni music dan seni rupa, dalam pembelajaran di sekolah
Madarasah Aliyah Negeri 1 Stabat seni rupa mempelari pelajaran kerajinan anyam. Melalui pendidikan seni budaya siswa dapat berkreasi untuk mencurahkan seluruh ide, pikiran, perasaan sehingga menghasilkan suatu karya seni yang bermanfaaat dan memperkaya khazanah kebudayaan. Seni rupa merupakan salah satu dari materi yang diajarkan disekolah, disebut dengan mata pelajaran Seni Budaya dan merupakan cabang seni yang membentuk karya dengan media penciptaan yang bisa ditangkap oleh mata dan dirasakan dengan rabaan. Khususnya seni rupa pada kerajinan anyam. Kerajinan anyam adalah karya seni yang menjadi hiasan biasanya akan menjadi benda pakai yang dapat digunakan ataupun merupakan mata pencarian masarakat desa maupun kota.

Kerajinan yang telah lama ditekuni oleh sebagian masyarakat diseluruh Indonesia bahkan dunia, kerajinan anyam merupakan budaya yang tidak terpisahkan dari masyarakat Indonesiaseperti daerah Jawa, Sumatera, Kalimantan, dan Bali adapun bahan yang beragam 
dari bahan alam sampai dengan bahan yang beragam daur ulang atau sintetis, misalkan bahan alam berupa pandan, bambu, rotan dan sebagainya. Sementara bahan yang dipakai adalah serat kelapa, tali sabut kelapa, dan sebagainya, begitu juga bahan sintetis berupa pita, tali kur dan sebagaina.

Kerajinan anyam adalah kerajinan yang merupakan peninggalan masa lalu tetapi sampai saat ini masih digemari dan dipelajari oleh masyarakat di Indonesia.

Kerajinan anyam merupakan salah satu karya seni rupa yang mempunyai banyak variasi dan keindahan yang dapat memukau setiap orang. Hasil yang beragam dan bisa dikombinasikan kedalam benda lain mempunyai daya tarik tersendiri.

Madrasah Aliyah Negeri 1 Stabat terdapat mata pelajaran Seni Rupa didalamnya terdapat pelajaran kerajinan anyam.Dimana anyaman memakai tali kur, Sekolah melatih siswa siswi untuk membuat karya benda dari tali kur. Berbagai bentuk diciptakan antara lain dari gelang hingga tempat pinsil,

Dalam proses menganyam siswa kelas X juga memakai teknik dalam mengerjakan, adapun anyaman yang dipakai siswa sekolah Madrasah Aliyah Negeri I Stabat yaitu teknik simpul. Teknik menganyam dengan menggunakan tali kur, hanya terbatas pada hasil produksi seperti tas, kotak pinsil, gantungan pot bunga, tali pinggang.

Sebenarnya warna pada tali kur ini cukup banyak, oleh karena tekniknya tidak banyak, sehingga untuk memperpadukan warna sangat sulit.Sehingga bentuk hasil kerajinan anyam ini kelihatan sangat monoton. Pada karya siswa kelas $\mathrm{X}$, kombinasi warna pada tali kur belum menunjukan warna yang harmonis, cenderung warna yang digunakan masih warna yang tersedia saja, tidak menggunakan warna-warna yang variasi, dikarenakan harga tali kur cukup mahal bagi para siswa, sehingga para siswa sulit memperoleh warna yang mereka butuhkan. 
Bentuk yang dihasilkan tidak beragam, masih cenderung kotak pinsil atau gelang saja, sehingga hasil yang dicapai pada siswa tidak berkembang dan tidak menarik, 334 ngingat teknik yang dihasilkan h anyaman tali kur sangat beragam tekniknya.

Pada hasil wawancara dengan guru Seni Budaya (Mutya Awanis Tanggal 5, Juni 2017). Siswa masih belum mengenal betul tentang anyaman tali kur, dimana bahan juga susah didapat, masih sedikit yang menjual bahan tai kur, wawasan terhadap perkembangan anyaman tali kur juga belum mereka ketahui, alhasil bentuk yang mereka kerjakan mendapat banyak kendala, seperti teknik yang dipakai, kombinasi teknik, bentuk yang monoton, seperti hanya gelang saja, dan perpaduan warna-warna yang harmonis masih sedikit pengetahuannya.

Pada dasarnya pengetahuan siswa tentang kerajinan anyam masih dapat dikatakan umum, pengetahuan siswa dalam pengolahan teknik, bentuk anyaman dan warnapada kerajinan anyaman masih sangat kurang variatif. Terlihat dari karya siswa yang kurang menarik, Siswa belum mampumenyusun warna tali kur serta teknik yang mereka pergunakan masih tergolong belum menguasai, Selain itu wawasan siswa tentang kerajinan anyaman belum banyak menjadikan karya siswa tidak berkembang. karena perpaduan teknik bentuk dan warna pada kerajinan akan mempengaruhi keindahan karya anyaman. Perlu adanya penyusunan warna, karena tidak semua warna dapat tersusun menjadi warna yang harmonis.

Berdasarkan permasalahan tersebut peneliti bermaksud meneliti hasil karya siswa kelas $\mathrm{x}$ dengan judul: ANALISIS KARYA KERAJINAN ANYAM TALI KUR SISWA KELAS X MADRASAH ALIYAH NEGERI 1 STABAT BERDASARKAN TEKNIK, BENTUK DAN WARNA.

\section{LANDASAN TEORI}

Kerangka teoritis adalah teoriteori yang menjadi acuan ataupun pedoman dalam penyelesaian suatu penelitian. Dalam hal ini 
penulis membuatsuatu landasan teoritis berdasarkan kajian dari berbagai kepustakaan yang berhubungan dengan masalah yang akan diteliti.

Untuk lebih memahami penelitian ini maka dalam kerangka teoritis akan dikemukakan mengenai beberapa teori yang relevan. Hal ini dilakukan untuk mempermudah penelitian dalam menguraikan masalah-masalah dalam penelitian ini, pandangan dan pendapat para ahli akan disusun dan dipadukan dalam penelitian ini.

\section{Pengertian Analisis}

"Analisis
penyelidikan terhadap suatu
peristiwa (karangan, perbuatan,
dan sebagainya) $r$ untuk
mengetahui keadaan yang
sebenarnya (sebab-musabab,
duduk perkaranya, dan
sebagainya); proses pencarian
jalan keluar (pemecahan masalah)
yang berangkat dari dugaan akan
kebenarannya; penyelidikan
terhadap suatu peristiwa untuk

mengetahui keadaan yang sebenarnya." (KBBI, 2007: 43).

Dalam kamus Ensiklopedia Nasional dijelaskan bahwa :

"Analisis adalah cara memeriksa suatu masalah untuk menemukan semua unsur dasar dan hubungan antara unsur-unsur yang bersangkutan. Oleh karena itu masalah yang diperiksa dapat diketahui susunannya." (Ensiklopedia Nasional Indonesia.1988: 19).

Berdasarkan dari kutipankutipan diatas, maka dapat ditarik kesimpulan bahwaanalisis adalah suatu usaha untuk mengetahui sebab musabab dan mengupas masalah-masalah lebih dekat melalui media perantara dengan hubungan dan peran untuk mengetahui keadaan yang sebenarnya pada masalah yang akan diteliti.

\section{Kerajinan}

Dalam Kamus Besar
Bahasa Indonesia,
$(1991: 811)$ "berasal dari
kata rajin, yang artinya
suka bekerja getol atau




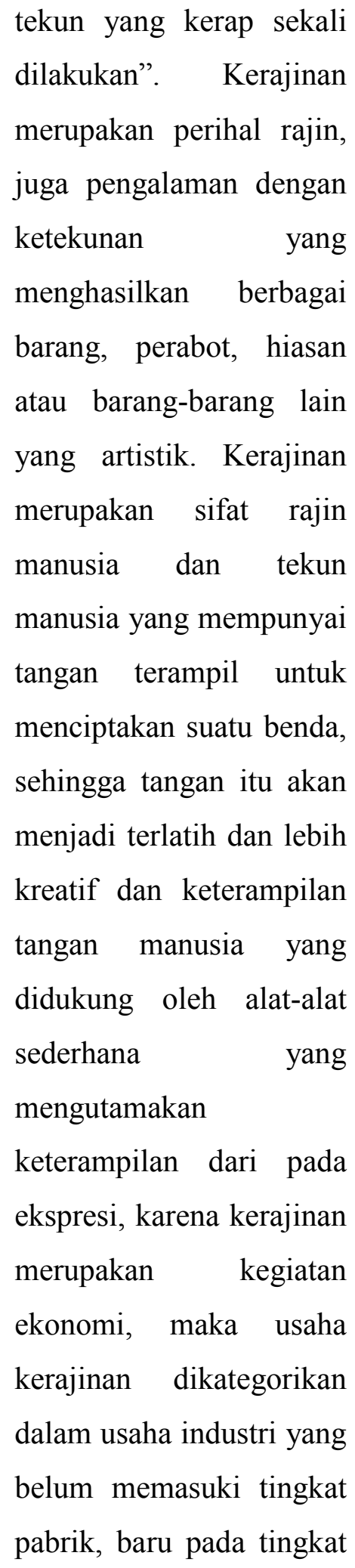

kerajinan rumah tangga

dan industri.

Pengertian kerajinan menurut Kusnadi (1983:11) adalah sebagai berikut:

Seni kerajinan menurut kata harfiahnya dilahirkan dari sifat-sifat rajin manusia.Namun harus kita sadari bahwa titik berat dari penghasilan dan pembuatan seni kerajinan, bukanlah dikarenakan dari sifat rajin manusia (sebagai lawan dari kata malas), melainkan lahir dari kata terampil atau keprigelan (Jawa) tangan kita. Keterampilan ini didapat dari pengalaman dengan tekun bekerja saja yang dapat meningkatkan cara atau teknik penggarapan serta memperdalam hasil kualitas kerja seseorang yang akhirnya memiliki skill atau keahlian bahkan kemahiran dalam suatu 
profesi

tertentu

(craftmanship).

Sedangkan pengertian kerajinan menurut Yudoseputro yaitu:

Demikianlah kerajinan atau karya yang dilandasi oleh usaha manusia untuk memenuhi kebutuhan hidup manusia, apabila didukung oleh perasaan dalam menggunakan alat dan bahan, maka hasilnya merupakan karya seni.Dan karena kerajinan dapat dilihat dan diraba, maka karya ini dapat termasuk kelompok seni yang disebut Seni Rupa.

Kerajinan dalam Kamus Besar Bahasa Indonesia adalah perihal rajin;kegiatan; kegetolan, barang yang dihasilkan melalui keterampilan tangan menurut Alwi Hasan, (2001:992). Kerajinan berasal dari kata "rajin" mendapat awalan ke- dan akhiran -an, dimana kerajinan disini bersifat melatih diri ke arah rajin (gerakan aktif). Gerakan aktif tersebut sudah bisa dikerjakan sejak kecil baik sengaja maupun tidak sengaja, sebagai contoh: anyaman, potong-potongan pakaian, melipat-lipat kertas, mengukir kayu, batu, logam, gading, batik, dan sebagainya, gerakan ini bersifat aktif.

Menurut Fahmi, (1997: 251). Hasil suatu seni kerajinan tangan disebut juga seni guna. Menurut Soeroto, (1993: 20) seni kerajinan merupakan usaha produktif di sektor nonpertanian baik untuk mata pencaharian utama maupun sampingan, oleh karenanya merupakan usaha ekonomi, maka usaha seni kerajinan dikategorikan ke dalam usaha industri

Jika dilihat dari bentuk dan wujudnya, karya kerajinan dapat digolongkan ke dalam kelompok seni rupa, Yudoseputro (1983:1) menjelaskan bahwa:

Demikianlah kerajinan atau karya yang dilandasi oleh usaha manusia untuk memenuhi kebutuhan hidup manusia, apabila didukung 


oleh perasaan dalam
menggunakan alat dan
bahan, maka hasilnya
merupakan karya seni.Dan
karena kerajinan dapat
dilihat dan diraba, maka
karya ini dapat termasuk
kelompok seni yang disebut
Seni Rupa.

Karya seni kerajinan digolongkan ke dalam kelompok seni rupa, karya seni kerajinan dalam proses penciptaan dan pembuatannya tidak terlepas dari unsur-unsur desain seperti garis, bidang, warna, dan tekstur, sehingga bentuk dan wujud dari sebuah karya seni kerajinan dapat dilihat dan diraba.

\section{a. Bahan-bahanAnyaman}

1. Mengkuang, terbuat dari daun mengkuang, contoh: tikar, tudung saji, dan lainlain

2. Buluh, terbuat dari jenisjenis buluh yang sesuai, contoh: bakul untuk bekas pakaian, nyiru, beg dan lain-lain.
3. Rotan, terbuat dari rotan yang telah diproses, contoh: bakul untuk bekas pakaian, tempat buaian anak dan lain-lain.

4. Lidi, terbuat dari lidi kelapa, contoh: lekar.

5. Ribu-ribu, terbuat dari tanaman paku pakis riburibu, contoh: tempat tembakau, bakul, dan lainlain.

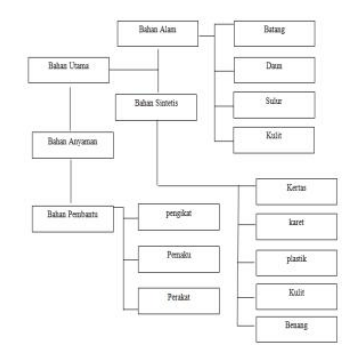

Gambar 2. 1Diagram Jenis-Jenis Bahan Anyaman

(Sumber: Kerajinan Anyam (Chairani)

\section{b. Jenis - Jenis Anyaman}

Dilihat dari ciri-ciri fisiknya, pada umumnya anyaman terbagi kedalam tiga jenis, yaitu sebagai berikut:

1) Anyaman Pita 


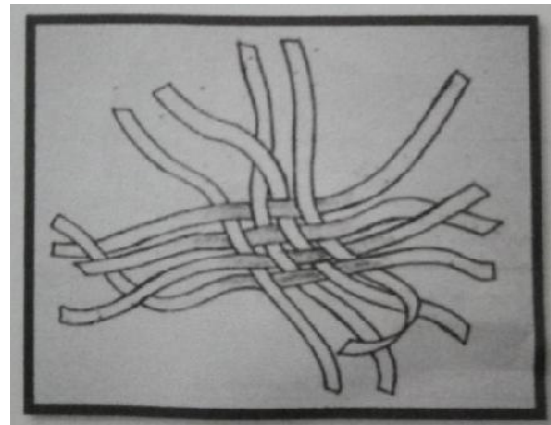

Gambar 2. Anyaman Pita

(Sumber:: Kerajinan Anyaman (Chairani, 2010:7)

Yaitu anyaman yang sifa anyamannya tipis, pipi seperti pita. Anyaman ini hanya bisa membuat dasar, bersegi, bersudut, dan tegak lurus. Tetapi anyaman pita banyak menghasilkan motifmotif anyaman.

\section{2) Anyaman Tali}

Yaitu sifat bahan anyaman bulat memanjang, anyaman ini dapat membuat bermacammacam bentuk yang diinginkan. Anyaman ini banyak dianyam untuk membuat barang-barang perabot rumah tangga seperti lemari, kursi, keranjang, bunga, tas dan lain sebagainya.

Gambar di bawah adalah hasil dari anyaman tali

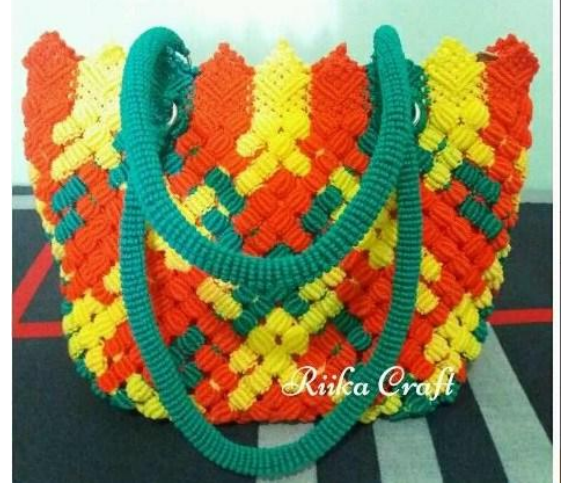

Gambar 2. 2 Hasil Anyaman tali

(Sumber: http://wahyu-

bluk.blogspot.co.uk/2015/02/tas-

kerajinan-talikur.html)

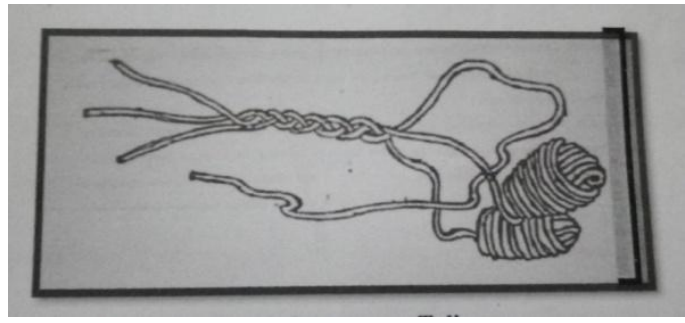

Gambar 2. 3 Anyaman Tali

(Sumber: Kerajinan Anyaman (Chairani, 2010:7)

3) Anyaman kerangka

Anyaman ini adalah yang dipadukan dengan bahanbahan pembantu misalnya kayu, besi, kawat dan sebagainya. Jenis anyaman dipadukan anyaman-anyaman pita dan tali

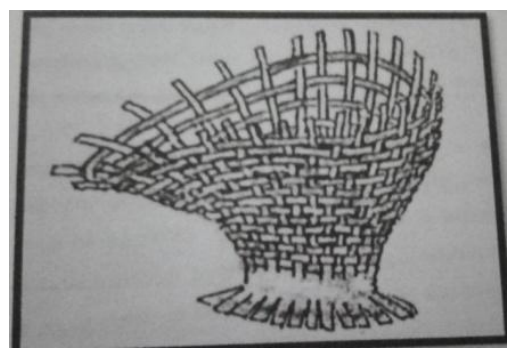


Gambar 2. 4 Anyaman Kerangka

(Sumber: Kerajinan Anyam (Chairani, 2010:7)

b). Anyaman Rotan

Setiap produk mungkin saja memiliki jenis anyaman yang sama atau berbeda. Jenis anyaman memang bermacam-macam. Setiap jenis berbeda cara mengerjakannya. Anyaman yang sering digunakan adalah anyaman sasag,

anyaman kepang, dan anyaman bersegi. Anyaman sasag banyak digunakan untuk pembuatan keranjang, anyaman kepang untuk pembuatan bilik, anyaman bersegi untuk pembuatan kursi rotan.

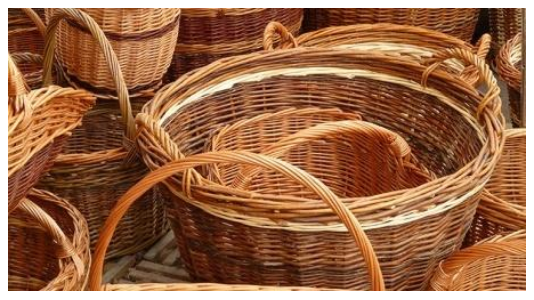

Gambar 2. 5Anyaman Rotan (Sumber: http://wahyubluk.blogspot.co.uk/2015/02/taskerajinan-talikur.html)

\section{Pengertian Anyaman}

Kerajinan anyaman merupakan kerajinan tradisional yang masih ditekuni sampai saat ini. Di samping banyak kegunaannya juga karena unsur kemudahaannya. Saat ini anyaman banyak mengalami perkembangan mulai dari bentuk dan motif yang bevariasi sehingga bentuk dan motif tidak kelihatan menoton.

Menurut Rian (2007: 12).Anyaman adalah tenunan yang dibuat dari susunan benang, bilaah, daun pandan dan sebagainya. Dengan tindih menindih, silang menyilang atau dipersilangkan miring dari kiri ke kanan dan kembali begitu seterusnya, sehingga didapat hasil anyaman,

Dengan demikian maka anyaman adalah suatu kegiatan keterampilan asyarakat dalam pembuatan barang dengan cara atau teknik susup menyusup, tindah menindih dan saling lipat melipatantara lungsing dan pakan sehingga saling menguatkan antara satu dengan yang lainnya, Rosna, (2009: 9) 
Dalam Oho Graha (2000:3) anyaman adalah suatu cabang kerajinan yang

telah sangat tua usianya. Menganyam merupakan suatu kegiatan menjalin bahan yang berbentuk pita sehingga satu sama lainnya saling kuat-menguatkan dan karena tekniknya, timbulah motif yang berulang.

Dari beberapa pendapat diatas, dapat disimpulkan bahwa anyaman merupakan ketrampilan tangan dengan teknik susupmenyusup, tindih menindih dan saling silang menyilang antara satu dengan yang lain.

\section{Pengertian Tali Kur}

Tali Kur / Macramé yang paling populer di zaman Victoria. Sylvia's Book Macramé Lace (1882), menjadi favorit, menunjukkan kepada pembacanya bagaimana mengerjakan banyak trimming dengan warna hitam dan warna pilihan, baik untuk dipakai di rumah, taman pesta, pantai, aksesories rumah-tangga dan lainlain. Dan ternyata ada juga yang menulis Sejarah atau asal usul tas macrame sebenarnya adalah teknik simpul macrame. Menggunakan teknik simpul khusus yang disebut macrame diciptakan oleh pria asal Ukraina Vladimir Denshchikov (1 Juli 1952 di Kiev). Kegemaran untuk kerajinan tali kur / macramé memudar, tapi populer kembali, untuk membuat hiasan dinding, bahan pakaian, seprai, celana pendek jins kecil, taplak meja, gorden, gantungan tanaman dan lainnya. Perhiasan Macramé menjadi populer di kalangan neohippie Amerika dan kerumunan grunge mulai pada awal 70-an. Yang sangat dominan menggunakan simpul persegi (square knot) dan simpul granny (banyak sekali jenis-jenis simpul). Jenis ini sering dipakai untuk membuat perhiasan tangan dengan manik-manik, kaca dan unsur-unsur alami seperti tulang dan kulit. Kalung, gelang tangan dan gelang kaki (belakangan banyak anak- dewasa memakainya di Indonesia) telah 
menjadi bentuk macramé yang populer.

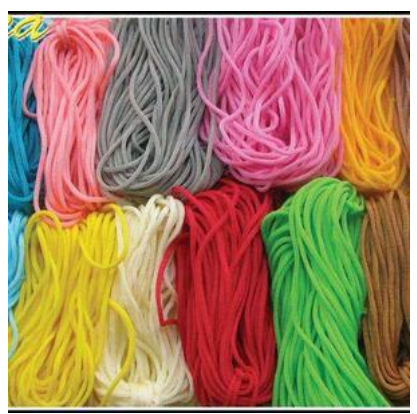

Gambar 2. 6 Tali Kur

(Sumber:

http://anyaman.pasarjepara.com/anyama

$\mathbf{n} /)$

Keunggulan anyaman dari talikur ini adalah bahannya yang kuat menjadikan karya kerajinan lebih awet dan tahan lama. Dan model yang unik dengan rangkaian tali yang disusun rapi dan dimodifikasi dengan tambahan rajutan bunga yang dipadukan oleh talikur, akan menjadikan karya seni talikur lebih cantik dipakai oleh penggunanya.

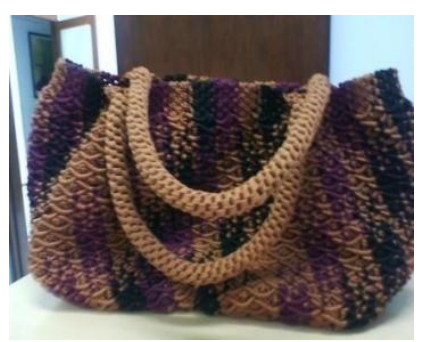

Gambar 2. 7 Hasil Kerajinan Anyam Tali Kur

(Sumber: http://wahyu-

bluk.blogspot.co.uk/2015/02/tas-kerajinantalikur.html)

Seni Kerajinan Makrame/tali kur adalah seni kerajinan yang memanfaatkan tali dan benang untuk menciptakan aneka ragam aksesoris dan produk. Seni ini juga maerupakan salah satu contoh seni rupa terapan.

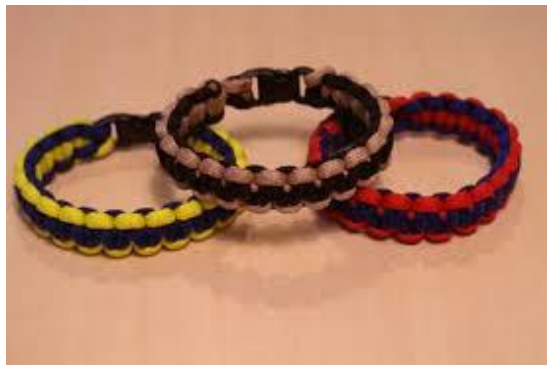

Gambar 2. 8 Prodak Gelang Dari Tali Kur

(Sumber: http://wahyu-

bluk.blogspot.co.uk/2015/02/tas-

kerajinan-talikur.html)

Teknik Pada Anyaman dan

Dasar-Dsar Menganyam

Didalam proses menganyam setiap prodak yang dihasilkan harus melalui teknik-teknik tertentu. Chairani (2012:21). Beberapa diantara teknik-teknik ini terdapat perbedaan sifat 
bahannya maupun motif-motif seperti teknik berikut ini

a) Anyaman Tegak

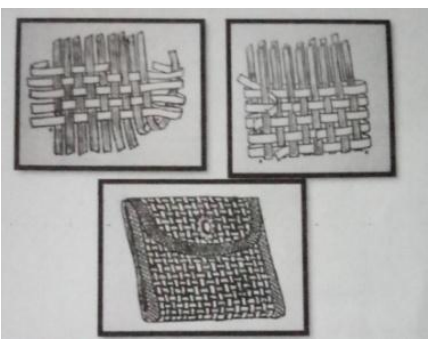

Gambar 2. 9 Cara Menganyam Dompet

Teknik Anyaman Tegak

(Sumber: Kerajinan Anyaman (Chairani, 2010:17)

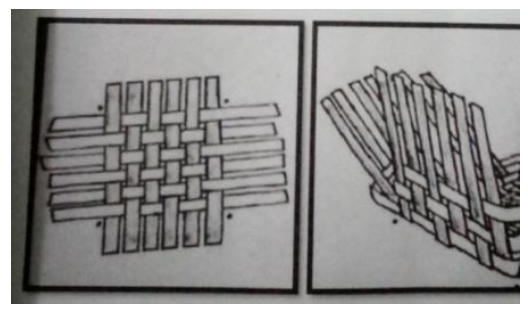

Gambar 2. 10 Cara Menganyam

Bakul/Keranjang, Teknik Anyaman Tegak

(Sumber: Kerajinan Anyaman (Chairani, 2010:18)

Anyaman tegak adalah menganyam dengan cara menambah iratan-iratan dari kiri kekanan serta dari atas ke bawah, begitu seterusnya sampai batas besar dompet dan bakul yang diinginkan.

b) Anyaman Miring

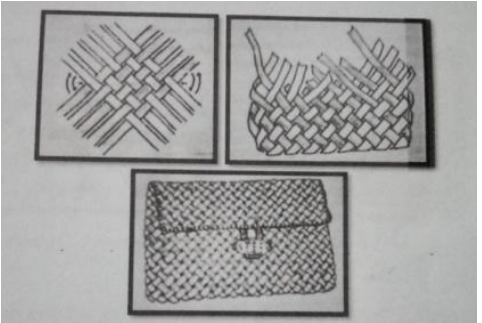

Gambar 2. 11 Membuat Dompet Dengan

Teknik Anyaman Miring

(Sumber: Kerajinan Anyaman (Chairani, 2010:19)

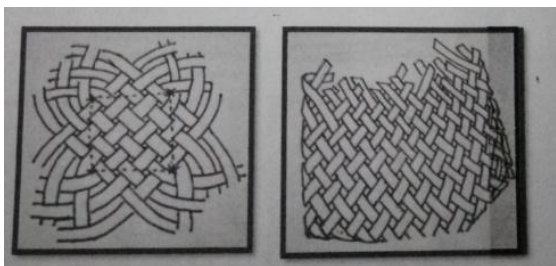

Gambar 2. 12 Cara Membuat Bakul

Dengan Teknik Anyaman Miring

(Sumber: Kerajinan Anyaman

(Chairani, 2010:20)

Anyaman miring adalah menganyam dengan cara menambah iratan-iratan menyerong/miring atau menambah sudut, begitu seterusnya sampai batas besar dompet/bakul yang diinginkan.

c) Anyaman Pita Tiga Anyaman pita tiga adalah yang memakai irataniratan dari tiga dengan menambah iratannya dari tiga arah ini akan menghasilkan lubang- 
lubang persegi enam, jika

jika iratan-iratan tersebut

diangkat dan dirapatkan

akan menimbulkan bentuk

wajik dan bunga.

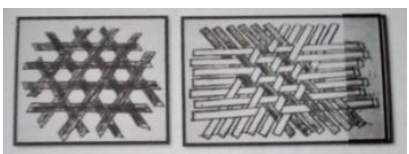

Gambar 2. 13 Anyaman Pita Tiga

Menimbulkan Lubang Segi Enam

(Sumber: Kerajinan Anyaman

(Chairani, 2010:21)

Anyaman pita ini dapat divariasikan

dengan

menambah iratan akan

lubang lubang segi empat

dan segi delapan.

Anyaman pita tiga dapat

dibuat bentuk kerajinan

seperti keranjang,

penyekat dinding, alas

gelas dan lain sebagainya.

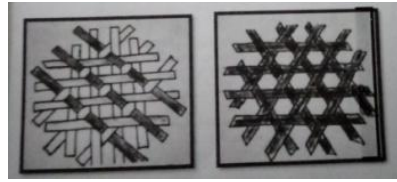

Gambar 2. 14 Kerajinan Berbagai Arah

(Sumber: Kerajinan Anyaman

(Chairani, 2010:22)

d) Anyaman Pinggir

Anyaman pinggir adalah anyaman yang memakai dua iratan, kemudian diselipkan dua iratan

dengan menekuk dan

dilipat meruncing seperti renda.

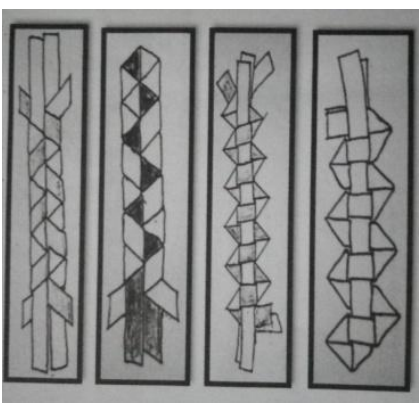

Gambar 2. 15 Anyaman Pinggir

(Sumber: Kerajinan Anyaman

(Chairani, 2010:23)

Anyaman pinggir selalu digunakan sebagai anyaman yang diletakan disebelah pinggir anyamanuntuk menutupi sisa-sisa anyaman. Produk anyaman ini menghasilkan barang jadi seperti, tas topi, dompet, tudung saji dan sebagainya

e) Anyaman Tali

Anyaman tali yaitu anyaman yang menggunakan iratan bentuk bulat berupa tali. Jenis anyaman ini dapat dipilin atau digulung, kemudian dapat juga 
dianyamkan pada bahan

pembantu dan dapat

digunakan

sebagaipengikat anyaman

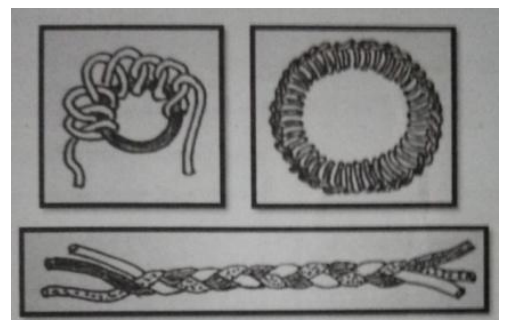

Gambar 2.16 Anyaman Tali

(Sumber: Kerajinan Anyaman

(Chairani, 2010:24)

f) Anyaman Kepang

Anyaman kepang yaitu anyaman tali yang dikepang, semakin banyak iratan yang dikepang semakin lebar anyaman yang dihasilkan. Anyaman kepang dapat menghasilkan tas, tali pinggang dan lain sebaginya

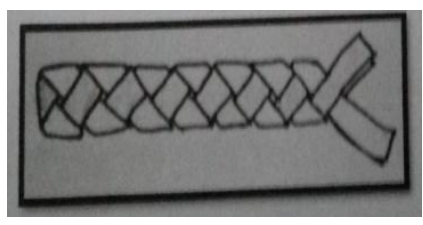

Gambar 2. 17 Anyaman Kepang

(Sumber: Kerajinan Anyaman

(Chairani, 2010:25)

g) Anyaman Berlubang
Anyaman berlubang yaitu anyaman yang memakai dua iratan kemudian diselipkan sehingga menimbulkan lubanglubang yang bervariasi. Hasil dari anyaman ini tebal karena iratannya dua lapis

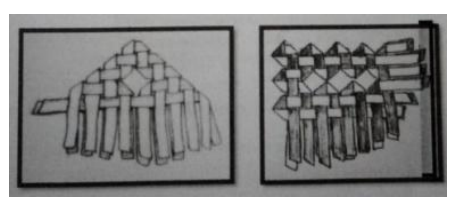

Gambar 2. 18 Anyaman Berlubang

(Sumber: Kerajinan Anyaman

(Chairani, 2010:26)

h) Anyaman Melingkar

Anyaman melingkar yaitu anyaman tali yang melingkar dari pusat atau tengah. Iratan pertama terdiri dari dua iratan, kemudian dua iratan ini dianyam melingkar sampai batas yang diinginkan.

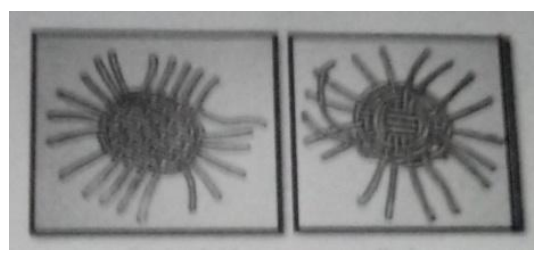




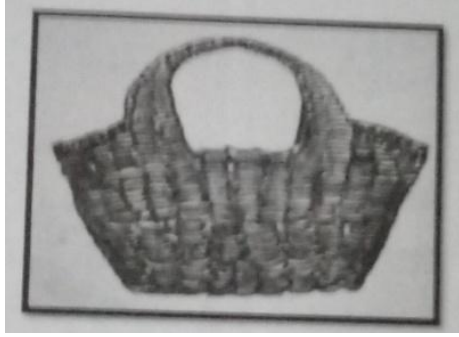

Gambar 2.19 Anyaman Melingkar

(Sumber: Kerajinan Anyaman (Chairani, 2010:27)

Anyaman melingkar dapat menghasilkan bentukbentuk anyaman seperti bakul, vas bunga, tempat surat, bentuk hewan, tempat tissu, dan lain sebagainya.

i) Anyaman Simpul Ikat Anyaman simpul ikat tali adalah tali adalah anyaman tali yang langsung memakai dua tali. Pertama tali disimpul kemudian ditarik sehingga simpul terikat.

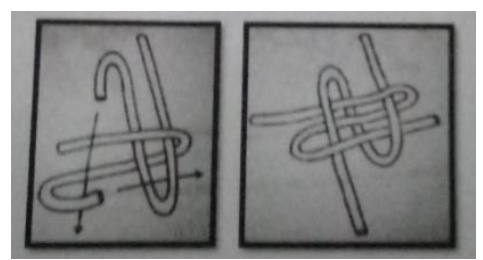

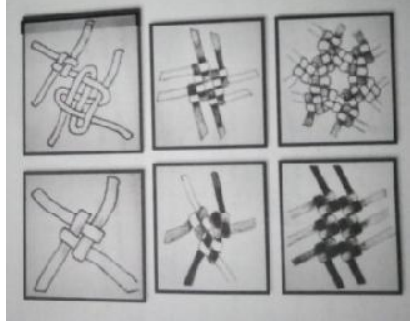

Gambar 2. 20 Anyaman Simpul Ikat (Sumber: Kerajinan Anyaman (Chairani, 2010:28)

j) Anyaman Kerangka Anyaman kerangka yaitu anyaman yang memakai kerangka untuk tempat iratan-iratan tersebut dianyamkan pada kerangka. Bahan yang dipakai diteknik ini adalah tali dan bahan dari kulit, kain. Sedangkan kerangkanya bisa menggunakan kayu dan besi. Anyaman kerangka dapat dibuat untuk hiasan dinding, sekat dinding dan sebagainya.

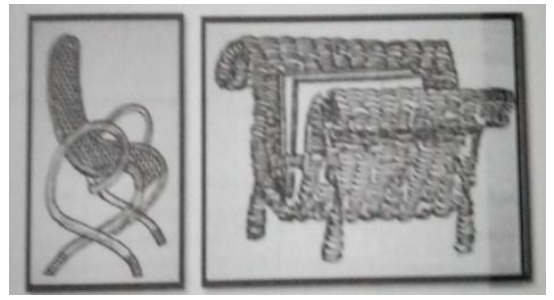

Gambar 2. 21 Anyaman Kerangka 
(Sumber: Kerajinan Anyaman

(Chairani, 2010:29)

\section{1).Macrame}

Menurut Wardana, (2003:44) dari kebiasaan membuat simpul yang fungsional dan artistik itu pada akhirnya muncul seni kerajinan yang khusus menggunakan teknik ikatmengikat tanpa bertujuan menguatkan benda lain seperti yang semula dilakukan. Banyak jenis kerajinan makrame yang sepenuhnya merupakan kegiatan ikat mengikat yang tidak untuk mengikatkan ujung sesuatu tenunan seperti yang semula. Hasil Jadi dilakukan. Di antara jenis-jenis kerajinan simpul atau makrame yang berupa benda assesories rumah adalah penghias gerabah ataukeramik, tas, hiasan dinding, keranjang untuk menggantung tanaman,gorden, taplak meja, kap lampu, sarung bantal dan sebagainya.Sedangkan assesories busana adalah ikat pinggang, gelang, topi,rompi, dompet, kerudung penutup bahu dan punggung, tempat kacamata, kalung dan lain-lain. Pokoknya demikian banyak benda yangdapat dibuat dengan teknik makrame atau menyimpul

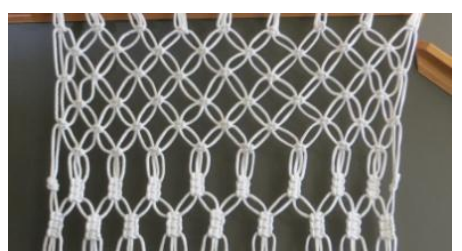

Gambar 2. 22 Teknik Makrame/ Menyimpul

(Sumber: wahyu-bluk.blogspot.co.uk)

\section{Pengertian Teknik}

Menurut Humar Sahman (1993:55) Teknik adalah segala macam cara atau ketrampilan yang digunakan dalam mengolah segala unsur bahan menggunakan peralatan menjadi sebuah karya seni rupa yang menarik.

Teknik menurut Humar Sahman (1993:30), teknik adalah mengolah bahan menurut tuntunan ide, sedangkan ide itu sendiri mengembangkan

perasaan menurut kaidah-kaidah bentuk. Kedua olahan itu pada 
dasarnya bersifat pribadi, yang disebut teknik. Seni

Kriya dapat dikerjakan dengan berbagai teknik tergantung dari bahan dan alat serta kreativitas pembuat/pengerajinnya.

Dalam terjemahan Kamus Bahasa Indonesia Poerwardaminta (1983): Teknik merupakan suatu pedoman untuk mengerjakan dengan atau tanpa bantuan alatalat, yang dilakukan seniman mengolah berbagai macam material menjadi suatu bentuk karya seni.

\section{Pengertian Bentuk}

Menurut Sahman

Bentuk atau bangun, yaitu unsur yang selalu berkaitan dengan benda, baik benda alami maupun buatan. Bantuk atau bangun benda dapat berupa bangun beraturan seperti lingkaran, segi empat segi tiga atau tidak beraturan.Selain berupa bangun, benda juga memiliki bentuk palstis.Sebuah kotak kayu memiliki bangun persegi empat, tetapi adanya tekstur dan kesan gelap terang membuat pengamat dapat melihat bentuk plastisnya.

\section{Pengertian Warna.}

"Unsur rupa yang paling mudah di tangkap oleh mata adalah warna. Unsur ini juga yang paling mudah menimbulkan kesan pada perasaan, sehingga merupakan yang paling akrab dikenal manusia”. (Sipahelut, 1991:99).

Menurut Sakdiah dan Tri Atmojo (2009: 59) menyatakan bahwa warna adalah gelombang cahaya dengan frekuensi berbeda yang mempengaruhi penglihatan kita. Mengapa suatu benda dapat dikenali dengan berbagai warna, karena secara alami mata kita dapat menangkap cahaya yang dipantulkan dari permukaan benda tersebut."

Menurut Sembiring (2014: 141) dalam buku wawasan seni menyebut Pemakaian warna dalam seni rupa terbagi menjadi tiga warna yaitu warna primer (warna dasar), warna sekunder (percampuran warna primer), dan warna tersier 
(percampuran antara warna primer dan skunder).

\section{a). Warna Primer}

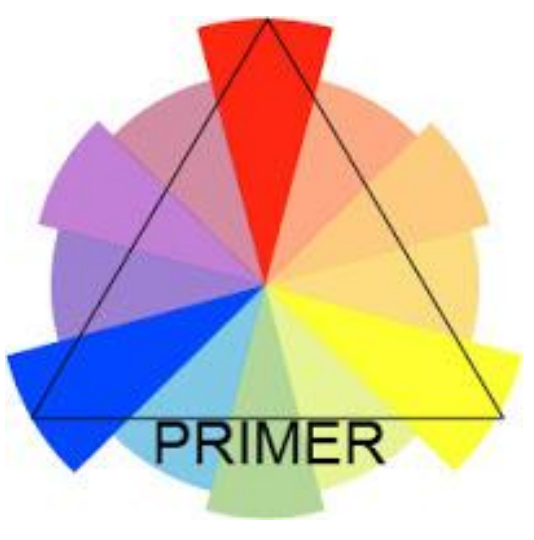

Gambar 2. 23Warna Primer

(Sumber :

http://irfanjulio.blogspot.co.id/2012/07/teo ri-warna-brewster.html)

\section{b). Warna Sekunder}

Warna sekunder atau disebut warna kedua adalah warna jadian dari percampuran dua warna primer. Warna sekunder adalah

1). Jingga/ orange, percampuran antara warna merah dan kuning,

2). Ungu/violet, percampuran antara warna merah dan biru.

3). Hijau, percampuran antara warna kuning dan biru.

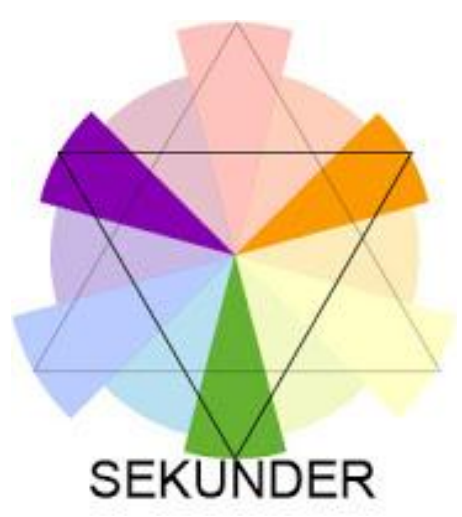

Gambar 2. 24Warna Sekunder

(Sumber :

http://irfanjulio.blogspot.co.id/2012/07/teo ri-warna-brewster.html)

\section{c). Warna Tersier}

Warna tersier atau warna ketiga adalah warna hasil percampuran dari dua warna sekunder atau warna kedua. Warna tersier adalah

1) Coklat kuning, disebut juga siena mentah, kuning tersier, yellow ochre atau olive, yaitu percampuran antara warna jingga dan hijau

2) Coklat merah, disebut juga siena bakar, merah tersier, burnt siena atau read brown, yaitu percampuran warna jingga dan ungu.

3) Coklat biru, disebut juga siena sepia, biru tersier, zaitun atau navy blue, yaitu percampuran warna hijau dan ungu. 


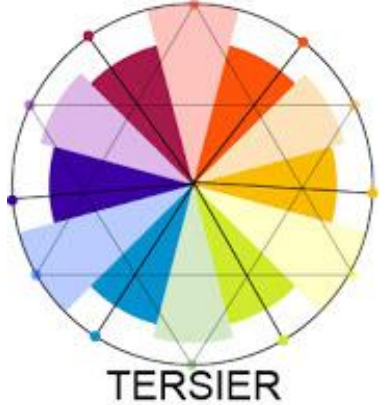

Gambar 2. 25 Warna Tersier

(Sumber :

http://irfanjulio.blogspot.co.id/2012/07/teo

ri-warna-brewster.html ).

"Unsur rupa yang paling mudah di tangkap oleh mata adalah warna. Unsur ini juga yang paling mudah menimbulkan kesan pada perasaan, sehingga merupakan yang paling akrab dikenal manusia”. (Sipahelut, 1991:99).

Suatu warna akan tampak lebih indah atau jelek jika diletakkan dalam kombinasi dengan warna lain. Apabila warna pasangannya cocok (selaras) maka warna tersebut tampak bagus, tapi sebaliknya jika pasangan tidak selaras maka warna tersebut akan tampak jelek. Hal ini sejalan dengan yang di kemukakan Sipahelut (1991: 104) menerangkan bahwa: "Bagus jeleknya suatu warna bergantung dari warna yang mendampinginya, warna bagus akan menjadi jelek jika kombinasinya tidak selaras, sebaliknya warna yang dianggap jelek akan tampak menarik kalau pandai mencarikan kombinasinya secara tepat".

Kita juga menghubungkan emosi dengan warna kita bercerita tentang biru yang identik dengan kesedihan, merah dengan kemarahan, dan hijau dengan iri. Warna dalam karya seni juga dapat memicu respons emosional yang kuat bagi pengamat.

\section{Susanto}

(2011:433)menjelaskan“Wa rna didefenisikan sebagai getaran atau gelombang yang diterima indera penglihatan manusia yang berasal dari pancaran cahaya melalui sebuah benda.warna menurut kejadiannya dibagi menjadi warna subtraktif dan aditif. Warna-warna aditif adalah warna-warna yang berasal dari cahaya disebut 
Gorga Jurnal Seni Rupa

Fakultas Bahasa dan Seni

Universitas Negeri Medan

p-ISSN 2301-5942

Volume 7, Nomor 1, Januari - Juni 2018

http://jurnal.unimed.ac.id/2012/index.php/gorga

spektrum, sedangkan

subtraktif adalah warna

yang berasal dari pigmen 
Konsep adalah gejala yang paling terpenting dalam penelitian yang akan digunakan sebagai alat menggambarkan fenomena dengan penjabaran masalah dari kerangka teoritis. Dalam hal ini kerajinan anyaman dari tali kur adalah kegiatan kreasi ide ataupun gagasan berupa bentuk visual.

Berdasarkan tinjauan observasi pada kelas X Madrasah Aliyah Negeri 1 Stabat dalam menghasilkan karya kerajinan. Ternyata karya siswa masihkurang baik dan memiliki kelemahan ditinjau dari teknik dan warna. menganyam yang dimaksudkan disisni menggunakan tali kut sebagai media objek yang dilukiskan yaitu gelang, tempat pinsil serta tempat botol miniman. Siswa kebanyakan kesulitan dalam memaksimalkan teknik dan warna sehingga pada bentuk kurang baik.

\section{METODE PENELITIAN}

Penelitian dilakukan di kelas X. Sekolah Madarasah Aliyah Negeri 1 Stabat.

\section{Waktu Penelitian}

Sesuai rumusan masalah penelitian, maka Penelitian ini dilaksanakan selama 3 bulan yaitu dari Maret sampai Mei 2017. Adapun rincian waktu kegiatan sebagai berikut:

\section{Populasi dan Sampel Penelitian}

\section{Populasi}

Dari ketiga pendapat di atas dapat ditarik kesimpulan populasi adalah jumlah dari keseluruhan pada objek penelitian. Adapun populasi dalam penilitian ini yaitu karya anyam dari tali kur oleh siswa kelas X. Madarasah Aliyah Negeri 1 Stabat. Populasi pada kelas X adalah sebanyak 4 kelas, dimana satu kelas sebanyak 35 siswa jadi keseluruhan semua siswa 140 siswa.

\section{Sampel}

Sampel pada penelitian ini menggunakan teknik proporsive sampling (Bertujuan). Adalah teknik pengambilan sampel didasarkan pada tujuan tertentu dengan memperhatikan ciri-ciri dan karakteristik populasi. Setiap karya dipilih dengan alasan mendapatkan 
karya yang maksimal. Maka sampel dalam penelitian ini adalah satu kelas dimana dalam satu kelas sebanyak 35 siswa.

\section{Teknik Pengumpulan Data}

Beberapa cara peneliti memperoleh dan mengumpulkan data. Yaitu dengan menggunakan teknik observasi, wawancara dan dokumentasi.

\section{Observasi}

Observasi diartikan sebagai pengamatan dan pencatatan secara sistematik terhadap suatu gejala yang tampak pada objek penelitian. Untuk menghasilkan data melalui observasi, dapat ditempuh dengan tiga cara, yaitu observasi langsung (direct observation), observasi tidak langsung (indirect observation) dan observasi terlibat (participant observation). Dalam penelitian ini penulis menulis melakukan observasi dengan cara observasi langsung (direct observation) danobservasi tidak langsung (indirect observation). Adapun data yang diambil melalui observasi ini adalah data awal yang menyangkut dengan latar belakang masalah.

\section{Dokumentasi}

Dokumentasi yakni dilihat dari karya-karya lukis, alat-alat dan bahan yang digunakan yang semuanya akan diamati dengan menggunakan kamera.

\section{Langkah-Langkah Penelitian}

Observasi dan dokumentasi karya-karya siswa untuk mendapatkan data-data yang dibutuhkan dalam penelitian. Langkah-langkah penelitian adalah sebagai berikut :

a. Menyusun kegiatan jadwal penelitian.

Dalam hal ini kegiatan disusun atau dijadwalkan sesuai jadwal yang ditetukan oleh pihak sekolah Sekolah Madarasah Aliyah Negeri 1 Stabat.

b. Observasi karya lukis siswa.

Observasi siswa penting untuk pemahaman awal keadaan yang ingin diteliti, dalam hal ini pembekalan siswa diberlakukan untuk mempersiapkan pembuatan karya kerajinan anyam dari tali kur. 
c. Mendokumentasikan karya lukis siswa.

Hasil karya siswa yang sudah dibekali dan cara pengerjaan siswa didokumentasikan.

d. Pengorganisasian karya kerajinan anyam siswa. Karya hasil siswa diorgansiskan sesuai dengan teknik sampling yaitu purposive sampling dimana karya yang diambil dalam penelitian selanjutnya.

e. Dari data yang terkumpul kemudian ditarik kesimpulan secara umum sebagai temuan dalam penelitian.

\section{Teknik Analisis Data}

Teknik analisis data yang digunakan dalam penelitian ini adalah teknik analisis data kualitatif yaitu mengumpulkan data informasi secara fakta yang diperoleh melalui hasil wawancara selanjutnya mengklasifikasi data yang penting dan penyusunan dilakukan secara sistematis. Langkah-langkah dalam menganalisis data dalam penelitian ini yaitu :
1. Mengklasifikasikan data berdasarkan indikator yang diamati dalam penelitian.

2. Penulis mengambil kesimpulan dari masingmasing indikator yang diteliti.

3. Penulis membuat kesimpulan secara keseluruhan dari indikator yang ditelitiHASIL PENELITIAN DAN PEMBAHASAN

\section{HASIL DAN PEMBAHASAN}

Data penelitian karya anyamyang dilakukan di kelas X. Sekolah Madarasah Aliyah Negeri 1 Stabat.Diperoleh dari beberapa Sumber Foto, antara lain Sumber Foto yang diambil berdasarkan metode observasi (peninjauan kesekolah, dan siswa), dokumentasi (membuktikan kebenaran karya dengan memfotonya). Semua metode ini memfokuskan pada karya kerajinan anyam seperti teknik, bentukserta penempatan warna yang dihasilkan siswa langsung. Dimana dijelaskan teknik, bentukserta penempatan 
warnamelalui gambardibawah ini berikut penjelasannya.

1. Teknik, bentuk dan warna, serta fungsi anyaman dari tali kur

a) Gelang Tangan

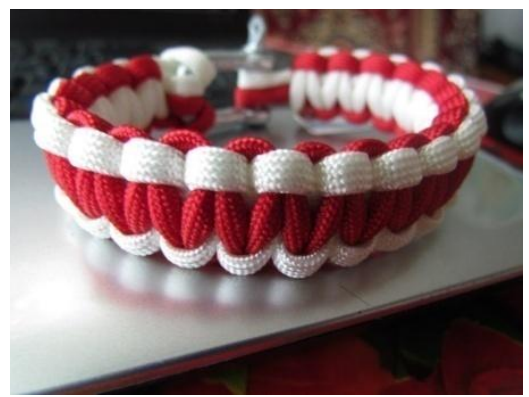

Gambar 4. 1Anyaman Gelang Tangandari Tali Kur

(Sumber: Citra Sari Ujung)

1) Teknik Anyaman Simpul Tunggal 1

Pada gambar diatas menunjukan hasil teknik dari siswa yang dilakukan di kelas X. Sekolah Madarasah Aliyah Negeri 1 Stabat, yaitu Teknik Anyaman Simpul Tunggal 1. Pada gambar di atas teknik sudah menunjukan hasil yang baik, menunjukan kerapiannya pada kerapatan anyaman terlihat pada bagian-bagian yang teranyam, beberapa hasil dari siswa yang masih terdapat kurang rapi pada.
2. Bentuk

Hasil penelitian kerajinan anyam siswa kelas $\mathrm{X}$ Madrasah Aliyah Negeri 1 Stabat, hasil menunjukan adalah bentuk anyaman gelang, bentuk yang terdapat seperti terdiri dari beberapa tali yang disatukan, dan membentuk sebuah kombinasi antara benang, seperti dililit antara benang satu dengan benang yang lainnya.

3. Warna

Pada gambar di atas keharrmonisasian warnasudah terlihat menarik, kombinasi dari warna putih dan warna merah muda sudah terlihat indah. Keharmonisasian terdiri dari warna yang cerah yaitu warna merah diperpadukan dengan warna putih, kontras warna dihasilkan oleh warna merah, dimana dominan warna merah menjadi pusat perhatian gelang tangan ini. 


\section{Pembahasan}

1. Analisis Karya Seni Kerajinan Anyam Tali Kur Siswa Kelas $\mathbf{X}$ Madrasah Aliyah Negeri 1 Stabat Berdasarkan Teknik BentukDan Warna

Keharmonisasian yang terdapat pada kerajinan anyam tali kur ini terlihat menunjukan warna yang kontras, kombinasi warna serta susunan warna yang selaras, tetapi ada juga dalam karya siswa kerajinan anyaman ini belum menunjukan warna yang harmonis, karena masih terdapat ketidaksesuaian pada susunan warna selaras dan warna kontras.

Langkah dasar yang telah diteliti maupun didokumentasikan oleh peneliti tentang kerajinan anyam dari tali kur yang dihasilkan siswa kelas $\mathrm{X}$ Madrasah Aliyah Negeri 1 Stabatmulai dari teknik, bentuk serta keharmonisasian warna

\section{SIMPULANDAN SARAN}

tentang teknik yang dipakai oleh siswa kelas X Madrasah Aliyah Negeri 1 Stabatadalah anyaman simpul tunggal, teknik, anyaman cengkeh dan simpung pangkal, simpul kordon diagonal dalam setiap hasil karya yang dibuat siswa yang menggunakan tali kur sebagai media berkarya dimana tali kur mudah dikombinasikan.

Hasil dari analisis data tentang bentuk yang dipakai siswa kelas $\mathrm{X}$ Madrasah Aliyah Negeri 1 Stabat.Hasil menunjukan adalah anyaman tas, gelang tangan, tempat minum, tempat tisu, tas dompet, bentuk yang dihasilkan siswa sudah terlihat baik, teradapat proporsi bentuk yang sudah baik.

Keharmonisasian warna yang terdapat pada karya siswa kelas $\mathrm{X}$ Madrasah Aliyah Negeri 1 Stabat. Keharmonisasian yang terdapat pada kerajinan anyam tali kur ini hampir menunjukan warna yang selaras, kombinasi warna dan susunan warna yang kontras, tetapi ada juga yang memakai satu warna. 
Berdasarkan hasil penelitian dan kesimpulan, maka peneliti menyampaikan beberapa saran sebagai berikut:

Tentang teknik pada kerajinan anyam tali kur

Bagi pihak sekolah agar kerajinan anyam menjadi kegiatan ekstrakulikuler yang dimana kerajinan anyam sangat menarik diminati siswa.

Tentang bentuk pada kerajinan anyam tali kur

Bagi pihak sekolah agar bentuk lebih kombinasikan dengan aksesoris lain, agar kerajinan anyam dari tali kur lebih indah.

Tentang keharmonisasian terhadapa kerajinan anyam tali kur

Bagi pihak sekolah teori warna lebih ditekankan agar siswa mengerti tentang susunan warna.

\section{DAFTAR RUJUKAN}

Alwi, Hasan. 2001. Kamus Besar Bahasa Indonesia.Jakarta: Balai Pustaka.

Arikunto, Suharsimi. 2010. Prosedur Penelitian: Suatu Pendekatan
Praktek, Edisi Revisi 2010.

Jakarta: PT Rineka Cipta.

Chace, S. (1981) :Crafts \& Hobbie, Reader's Digest.

Colton, V. (1979) :Complete Guide to Needlework, Reader's Digest.

Garha, Oho (2000), Penelitian kesenian SENI RUPA, Program Spesialisasi I. Jakarta:CV.Angkasa

Kusnadi. 1983. Peranan Seni Kerajinan (Tradisional dan Baru) dalam Pembangunan. Yogyakarta: Kanisius.

Mesra, 2005. Sentral Panel Gipsun Sebagai Alternatif

Pengembangan Kriya Seni. Jurnal Seni Rupa FBSUnimed. 2 (No.2) 127-141.

Mertosedono.Amir, 1994.Sejarah Wayang, Asal-Usul, Jenis dan Cirinya Semarang: Dahara Prize. 
Sahman, Humar, 1993Mengenali Dunia Seni Rupa, Tentang Seni, Karya Seni, Aktivitas Kreatif, Apresiasi, Kritik dan Estetika, UNS, Semarang.

Sipahelut, Atisah. 1991. Dasar-dasar Desain. Jakarta: Departemen Pendidikan dan Kebudayaan.

Soeroto, Noto. 1993. Wayang Lideran; Biografi Politik Budaya Noto Soeroto. Jakarta: Komunitas Bambu.

Susanto. Mikke. 2011. Diksi Rupa Yogyakarta. Dicti Art.......1967. Encyclopedia of World Art Vol. XII New York.

Sugiyono. 2014. Metode Penelitian Pendidikan (Pendeketan, Kuantitatif,Kualitatif, dan $R \& D)$. Bandung. Alfabeta.

Wardana, Enen. 2003. Aneka Kreasi dari Tali.Jakarta : Puspa Swara.
Wiyoso Yudoseputro.1983. Seni Kerajinan Indonesia, Jakarta. Direktorat Pendidikan Menengah Kejuruan, Dirjen P\&K 